\title{
PEMBERDAYAAN GURU TAMAN PENDIDIKAN AL-QURAN AL-ARDHI DAN NURUL JADID DI KABUPATEN SRAGEN MELALUI KETRAMPILAN BETERNAK AYAM KAMPUNG SECARA INTENSIF
}

\author{
Ratih Dewanti ${ }^{1)}$ dan Sudiyono ${ }^{1)}$ \\ 1) Prodi Peternakan, Fakultas Pertanian, \\ 2) Universitas Sebelas Maret, Surakarta \\ Email:Dewa_proter@yahoo.com
}

\begin{abstract}
ABSTRAK
Kegiatan PKM dilaksanakan di TPA Al-Ardhi dan Nurul Jadid Kabupaten Sragen. Metode yang digunakan adalah dengan memberikan penyuluhan, pelatihan, dan pendampingan pemeliharaan ayam kampung, penetasan, menyediakan peralatan lengkap, pelatihan pemasaran dan pembukuan sederhana serta pengolahan kotoran. Target luaran yang diharapkan adalah membentuk ustad dan ustadah TPA yang mandiri secara ekonomis dan breeding ayam kampung yang berkelanjutan. Dalam kegiatan ini di introduksikan kandang ren berpelataran, tempat pakan dan minum, mesin tetas full otomatis, eggtray, brooder, ayam kampung 44 ekor dan pakan. Hasil quisioner, terjadi peningkatan hasil sesudah penyuluhan dibandingkan sebelum penyuluhan (pengetahuan meningkat) sesudah penyuluhan yaitu 119 point dibandingkan sebelum penyuluhan 82 point. Puncak produksi telur pada umur ayam 35 minggu sebesar $76 \%$. Penjualan telur perbutir dengan harga Rp.2000-Rp.2500. Penetasan yang dilakukan memiliki daya tetas sebesar 74\%. Generasi F1 dijual umur kurang lebih 3 bulan dengan harga Rp.100.000/3 ekor. BEP harga produksi Rp.18.616/ekor. Melalui kegiatan ini, kemampuan dan ketrampilan ustad ustadah TPA Al-Ardhi dan Nurul Jadid mengalami peningkatan dan diharapkan mandiri secara ekonomis.
\end{abstract}

Kata Kunci: Ayam Kampung, Beternak, TPA, Al-Ardhi dan Nurul Jadid

\section{PENDAHULUAN}

Konsumsi daging ayam kampung di tingkat konsumen menunjukkan arah yang sangat positif dilihat dari banyaknya permintaan pasar terutama pada hari-hari besar keagamaan. Ketersediaan stock ayam kampung yang ada tidak mampu memenuhi kebutuhan pasar sehingga harga daging ayam kampung cenderung naik tidak seperti halnya ayam ras yang harganya sangat fluktatif. Hal ini dapat menjadi pertimbangan untuk tidak perlu ragu lagi memulai bisnis ayam kampung, dikarenakan kestabilan harganya dan bahkan cenderung naik menjadi salah satu syarat dalam menentukan usaha yang dapat menghasilkan keuntungan (Sartika, 2016). Kelebihan ayam kampung adalah mudah pemeliharaannya, dapat dipelihara dihalaman rumah, harga daging relatif lebih tinggi dan stabil dibanding ayam broiler, tahan penyakit, mudah beradaptasi, pakan mudah diperoleh, rasa daging lebih gurih dan dapat dimanfaatkan telurnya untuk konsumsi (Juliansyah, 2016). Mitra 1 TPA Al-Ardhi berdiri pada tahun 2000 beralamat di Dusun Lemahbang Rt.13 Rw. 05 Desa Plosokerep, Kecamatan Karangmalang, Kabupaten Sragen. Al-Ardhi 
Jurnal SEMAR Vol. 7 No. 2, 2018 hal. $23-31$

ISSN: 2302-3937 | Copyright (C LPPM Universitas Sebelas Maret

Homepage: https://jurnal.uns.ac.id/jurnal-semar

diketuai oleh Ustadah Titik Lestari. Mitra 2 TPA Nurul Jadid berdiri pada tahun 2005 beralamat di Dusun Wates Rt.14 Rw.06 Desa Plosokerep Kecamatan Karangmalang Kabupaten Sragen TPA Nurul Jadid dipimpin oleh Ustad Abdul Aziz.

Ustad dan ustadah bekerja secara ikhlas tanpa memperoleh gaji. Padahal mereka juga membutuhkan biaya untuk keperluan sehari-hari. Mereka ingin berwiraswasta sebagai usaha sampingan untuk mendapatkan penghasilan akan tetapi terbatas modal. Banyak ustadah yang sudah keluar dari TPA karena tidak kuat bekerja tanpa mendapatkan gaji. Sampai saat ini ketrampilan bidang peternakan untuk guru ustad dan ustadah masih belum ada. Padahal mereka perlu sekali mempunyai bekal ketrampilan usaha untuk kerja sampingan. Memelihara ayam dan penetasan merupakan kegiatan yang jelas bisa dilakukan para ustad dan ustadah. Pemasaran hasil beternak berupa daging dan telur ayam kampung masih sangat terbuka luas dengan tingginya permintaan daging dan telur ayam kampung di kabupaten Sragen yang belum terpenuhi. Dengan melihat kondisi ini, kegiatan pemberdayaan sangat bermanfaat bagi guru ustad dan ustadah sehingga diharapkan setelah dilakukan pengabdian ini, ustad dan ustadah menjadi lebih berdaya, mendapatkan penghasilan tetap dengan menguasai usaha beternak ayam kampung secara intensif dan usaha akan tetap terus berjalan walaupun pengabdian telah selesai dilakukan. Tujuan dari pengabdian ini adalah membentuk ustad ustadah yang mempunyai kemampuan beternak ayam kampung secara produktif sehingga mandiri secara ekonomis, dan Breeding ayam kampung yang berkelanjutan.

\section{METODOLOGI}

Kegiatan pengabdian ini dilakukan dengan metode penyuluhan, pendampingan, pelatihan manajemen pemeliharaan dan produksi ayam kampung sekaligus breeding.

\section{HASIL, PEMBAHASAN DAN DAMPAK}

Pengabdian dilaksanakan di TPA Al-Ardhi dan Nurul Jadid Kabupaten Sragen. Hasil yang sudah dicapai yaitu telah dibangunnya kandang ren berpelataran (ada rumah dan umbaran) beserta perlengkapan tempat pakan, minum, introduksi mesin tetas full otomatis, eggtray, brooder (kandang DOC), nest (sarang) desinfeksi kandang dan telah dipeliharanya ayam kampung. Penyuluhan sudah dilaksanakan pada hari Sabtu, 28 April 2018. Pelatihan penggunaan mesin tetas dilakukan pada Hari Minggu 22 Juli 2018. Mesin sudah digunakan dan berhasil melakukan penetasan dengan tingkat daya tetas $80 \%$. Hasil quisioner, terjadi peningkatan hasil sesudah penyuluhan dibandingkan sebelum penyuluhan.

Kandang ayam yang di introduksikan berupa kandang ren berpelataran dimana ada rumah (berlindung dari panas, hujan) serta berupa umbaran berbahan semen, kawat Ram dan kayu. Jumlah keseluruhan ayam kampung yang disiapkan adalah 44 ekor. Alas kandang berupa litter dari sekam padi bercampur kapur. Tempat pakan dan minum berbahan plastik. Kandang tersebut dibangun di belakang TPA. Photo-photo terlampir 
Jurnal SEMAR Vol. 7 No. 2, 2018 hal. $23-31$

ISSN: 2302-3937 | Copyright (C LPPM Universitas Sebelas Maret

Homepage: https://jurnal.uns.ac.id/jurnal-semar

\section{a. Kegiatan Penyuluhan}

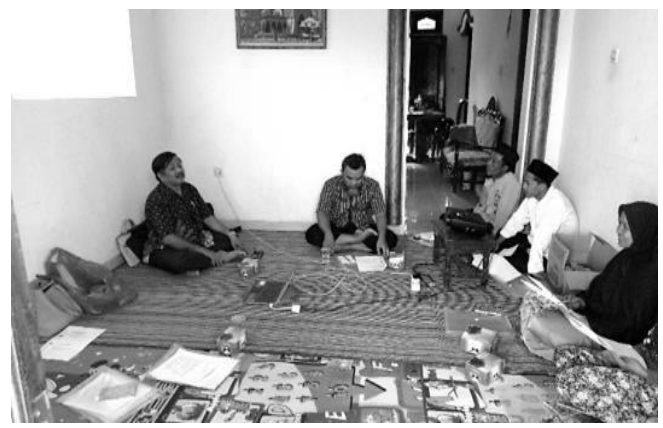

Gambar 1. Penyuluhan beternak ayam kampung di TPA Al-Ardhi dan Nurul Jadid.

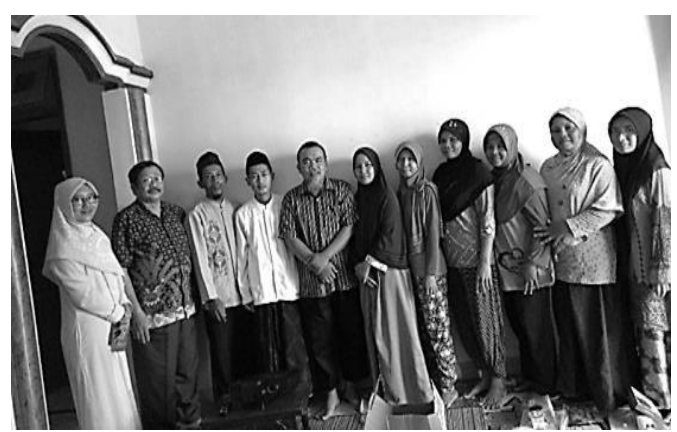

Gambar 2. Foto bersama setelah penyuluhan

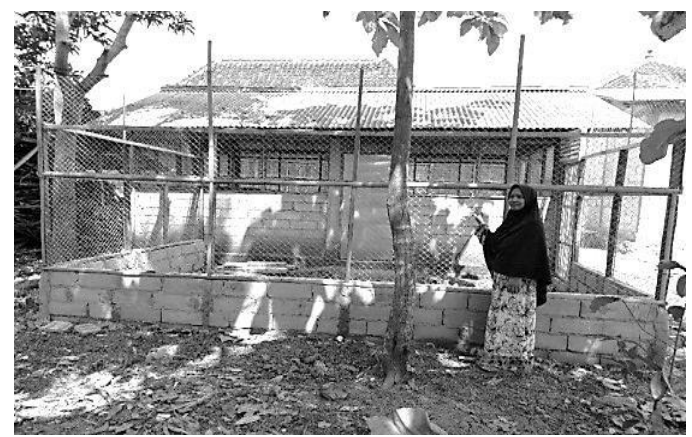

Gambar 3. Kandang Ren Berpelataran. 

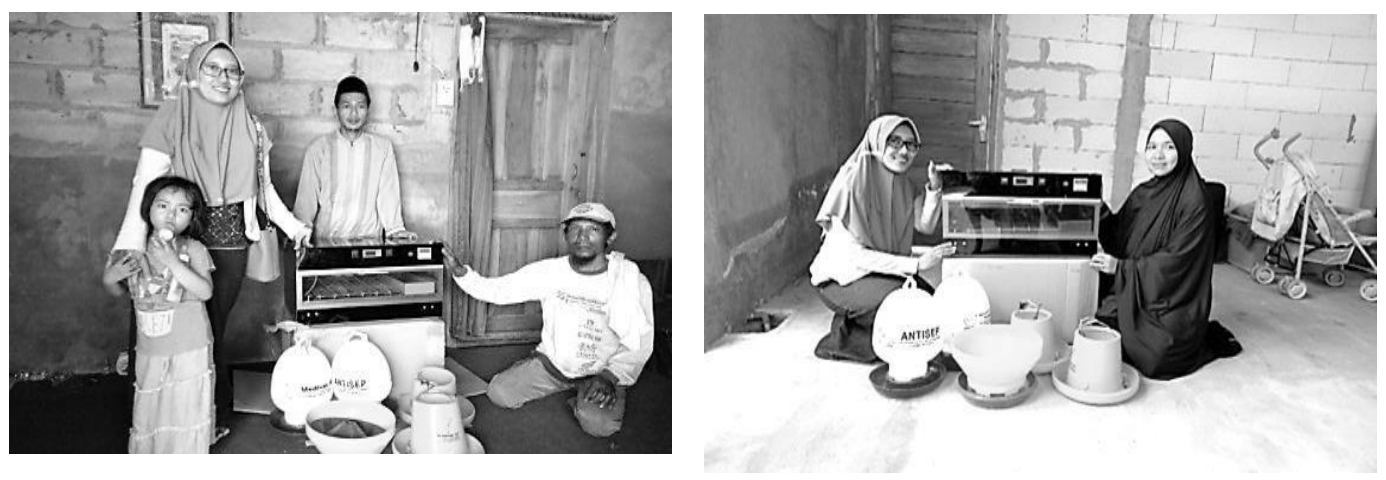

Gambar 4. Introduksi Mesin tetas dan tempat pakan minum

Kegiatan penyuluhan dilakukan untuk mentransfer Iptek dari Tim kepada kelompok sasaran untuk memecahkan persoalan yang dihadapi. Penyuluhan sudah dilakukan oleh Tim pada tanggal 28 April 2018 pukul 14.00 sampai 17.00 WIB di TPA Al-Ardhi Lemahbang Kabupaten Sragen. Penyuluhan mengundang seorang narasumber Ir.Sudiyono, MS yang berkompeten dibidang nutrisi pakan ayam. Penyuluhan meliputi manajemen penetasan,pemeliharaan, pakan, perkandangan dan penyakit-penyakit yang sering menjangkiti ayam kampung. Penyuluhan diikuti kurang lebih 10 guru TPA (ustad dan ustadah) dari kedua TPA. Menurut Amanah (2007) penyuluhan merupakan ilmu dan gerakan transformasi masyarakat melalui pengembangan potensi yang dimiliki dengan pendekatan edukasi, melakukan upaya penyelesaian masalah, menuju tatanan kehidupan yang lebih bermutu dan bermartabat. Peningkatan pengetahuan merupakan satu aspek mendasar yang dijadikan parameter keberhasilan penyuluhan. Pengukuran pengetahuan peserta sebelum dan sesudah penyuluhan merupakan salah satu cara evaluasi terhadap efektivitas peran dan kegiatan penyuluhan. Untuk itu dalam kegiatan ini dilakukan pre test dan post test yang hasilnya dapat dilihat pada Tabel 1 dan 2.

\section{Tabel 1. Hasil Quisioner Penyuluhan Beternak Ayam Kampung di TPA Al-Ardhi}

\begin{tabular}{llccc}
\hline NO & NAMA & $\begin{array}{c}\text { UMU } \\
\mathbf{R}\end{array}$ & $\begin{array}{l}\text { NILAI SEBELUM } \\
\text { PENYULUHAN }\end{array}$ & $\begin{array}{c}\text { NILAI SESUDAH } \\
\text { PENYULUHAN }\end{array}$ \\
\hline 1 & Suwarsini & 31 & 7 & 11 \\
2 & Titik Lestari & 41 & 9 & 12 \\
3 & Praditya Putri & 18 & 7 & 12 \\
4 & Sri Murniati & 27 & 6 & 12 \\
5 & Agus Sriyono & 47 & 10 & 12 \\
\hline & JUMLAH & & $\mathbf{3 9}$ & $\mathbf{5 9}$ \\
\hline
\end{tabular}

Keterangan: Nilai yang tercantum adalah nilai jumlah jawaban benar 
Jurnal SEMAR Vol. 7 No. 2, 2018 hal. $23-31$

ISSN: 2302-3937 | Copyright (C LPPM Universitas Sebelas Maret

Homepage: https://jurnal.uns.ac.id/jurnal-semar

Tabel 2. Hasil Quisioner Penyuluhan Beternak Ayam Kampung di TPA Nurul Jadid

\begin{tabular}{|c|c|c|c|c|c|}
\hline NO & NAMA & UMUR & ASAL & $\begin{array}{l}\text { NILAI SEBELUM } \\
\text { PENYULUHAN }\end{array}$ & $\begin{array}{l}\text { NILAI SESUDAH } \\
\text { PENYULUHAN }\end{array}$ \\
\hline 1 & Abdul Aziz & 34 & & 11 & 12 \\
\hline 2 & Suparni & 50 & & 7 & 12 \\
\hline 3 & Suripto & 42 & & 9 & 12 \\
\hline 4 & Mahar al & 30 & & 8 & 12 \\
\hline 5 & Sulis & 39 & & 8 & 12 \\
\hline & JUMLAH & & & 43 & 60 \\
\hline
\end{tabular}

Tabel 1 dan 2 menunjukkan bahwa dari segi umur peserta pelatihan dan penyuluhan berada pada rentang (18-50 tahun). Ustad dan ustadah secara fisik sangat bisa mengerjakan pekerjaan usaha ternak secara maksimal. Karakteristik peserta penyuluhan seluruhnya adalah ustad dan ustadah TPA.

Sebelum dan sesudah penyuluhan dilakukan pembagian quisioner. Dari hasil quisioner didapatkan data bahwa setelah penyuluhan tingkat jawaban yang betul mengalami kenaikan yang cukup signifikan yaitu untuk TPA Al- Ardhi dari 39 menjadi 59 point sedangkan untuk Nurul Jadid dari 43 menjadi 60 point. Hal ini menggambarkan bahwa dengan diadakannya penyuluhan ternyata sangat dapat meningkatkan pengetahuan dan wawasan Guru TPA tentang pemeliharaan ayam kampung. Bahkan setelah penyuluhan sebagian besar mendapatkan nilai penuh (betul semua) yaitu angka 12. Ustad ustadah dari Nurul Jadid mendapatkan nilai lebih unggul dibandingkan Al-Ardhi. Hal ini diduga karena ustad dari Nurul Jadid banyak yang sudah terbiasa memelihara ayam kampung.

\section{MONITORING DAN PENDAMPINGAN PEMELIHARAAN AYAM KAMPUNG}

Dalam suatu kegiatan, monitoring dan pendampingan sangat diperlukan untuk mengetahui sejauh mana kegiatan telah berjalan, apakah sesuai dengan yang direncanakan atau tidak dan juga untuk mengetahui kendala dan hambatan yang timbul. Dengan adanya monitoring dan pendampingan kegiatan bisa dikontrol dan apabila masalah yang menghambat ditemui, bisa segera dilakukan tindakan untuk mengatasi masalah tersebut.

Monitoring dan pendampingan ayam kampung dilakukan mulai pembangunan kandang, pembersihan, desinfeksi, pemeliharaan ayam kampung berumur $>20$ minggu sampai bertelur, melakukan penetasan dan pemeliharaan di brooder. Pendampingan dan monitoring pada awal pemeliharaan dilakukan hampir setiap tiga hari sekali karena pengabdian ini berhubungan dengan benda hidup yang masih rawan terserang penyakit. Pendampingan meliputi pelatihan dan pengarahan dari pembersihan kandang, desinfeksi, vaksinasi, pemberian pakan, minum, vitamin, obat dan sanitasi. Penetasan ayam kampung sangat berhasil dengan daya tetas $80 \%$. Saat ini generasi sampai F1 dan masih berumur satu bulan. Breeding akan tetap terus dilanjutkan sehingga TPA tidak hanya menjual telur konsumsi, akan tetapi juga menjual DOC (Kuthuk ayam) dan 
Jurnal SEMAR Vol. 7 No. 2, 2018 hal. $23-31$

ISSN: 2302-3937 | Copyright (C LPPM Universitas Sebelas Maret Homepage: https://jurnal.uns.ac.id/jurnal-semar

Ayam Dara.
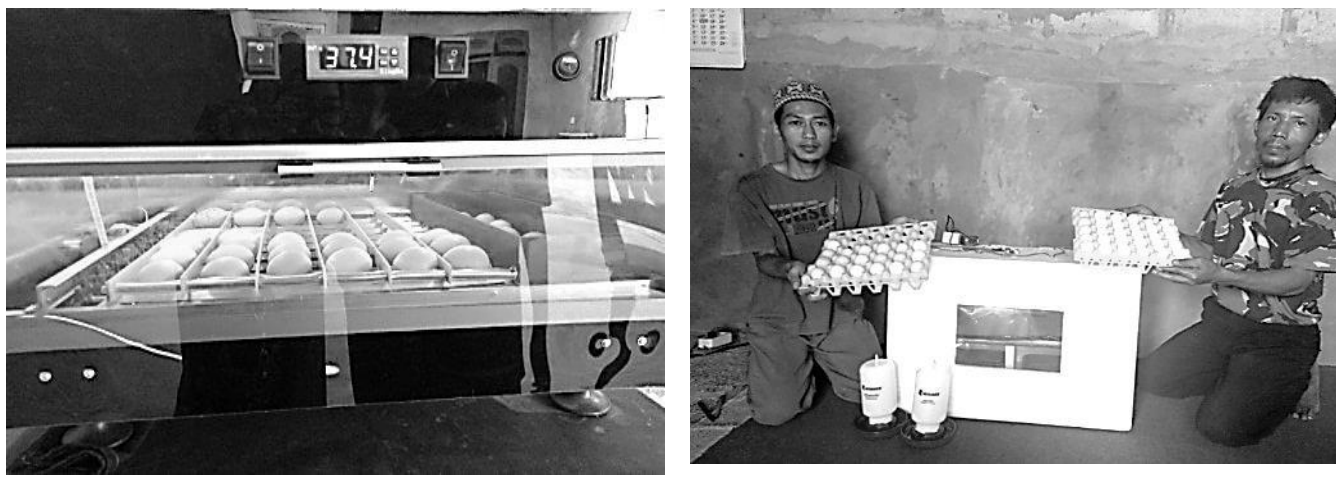

Gambar.5. Penetasan telur ayam kampung.

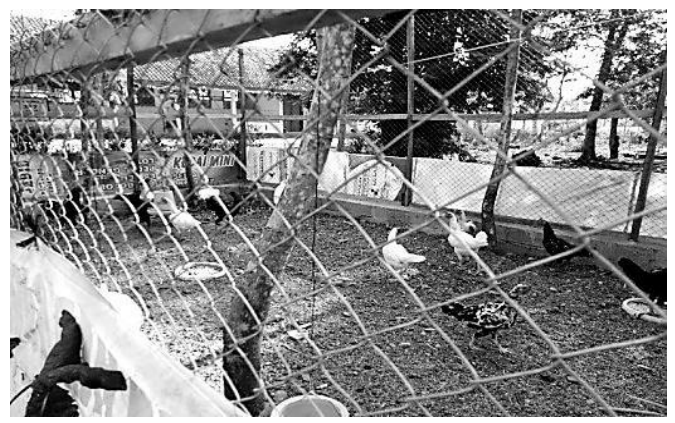

Gambar 6. Ayam kampung di kandang umbaran.

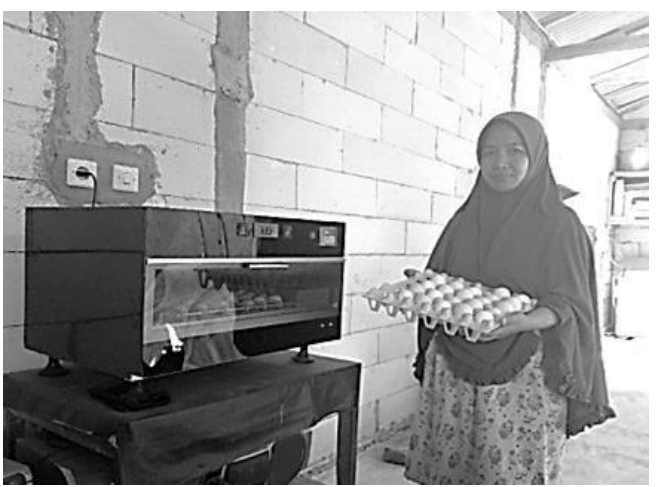


Jurnal SEMAR Vol. 7 No. 2, 2018 hal. 23 - 31

ISSN: 2302-3937 | Copyright (C LPPM Universitas Sebelas Maret Homepage: https://jurnal.uns.ac.id/jurnal-semar
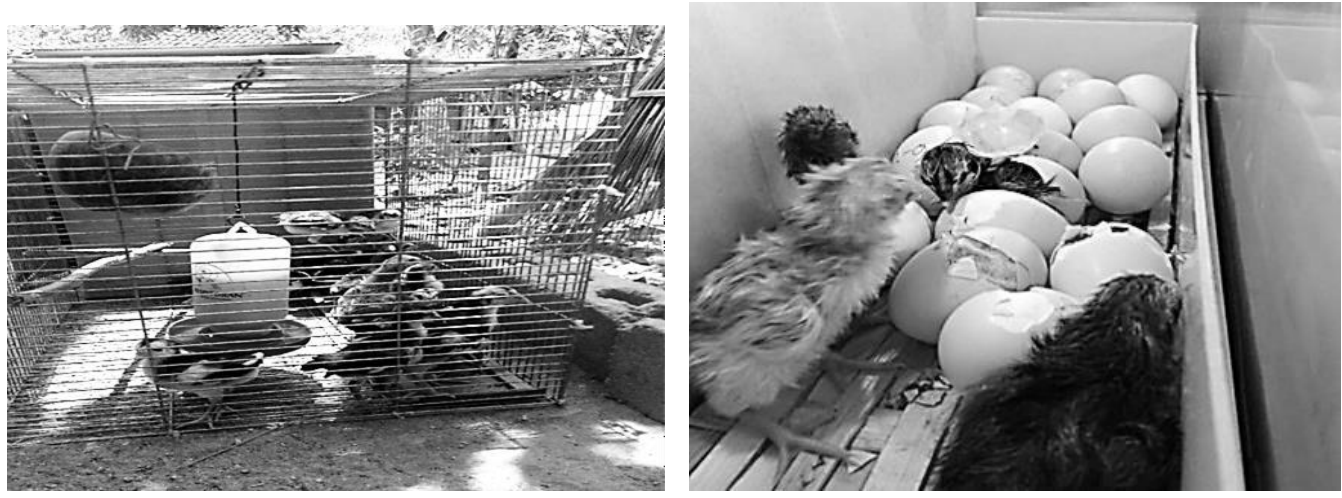

Gambar 8. Hasil penetasan dan generasi F1

\section{ANALISIS USAHA}

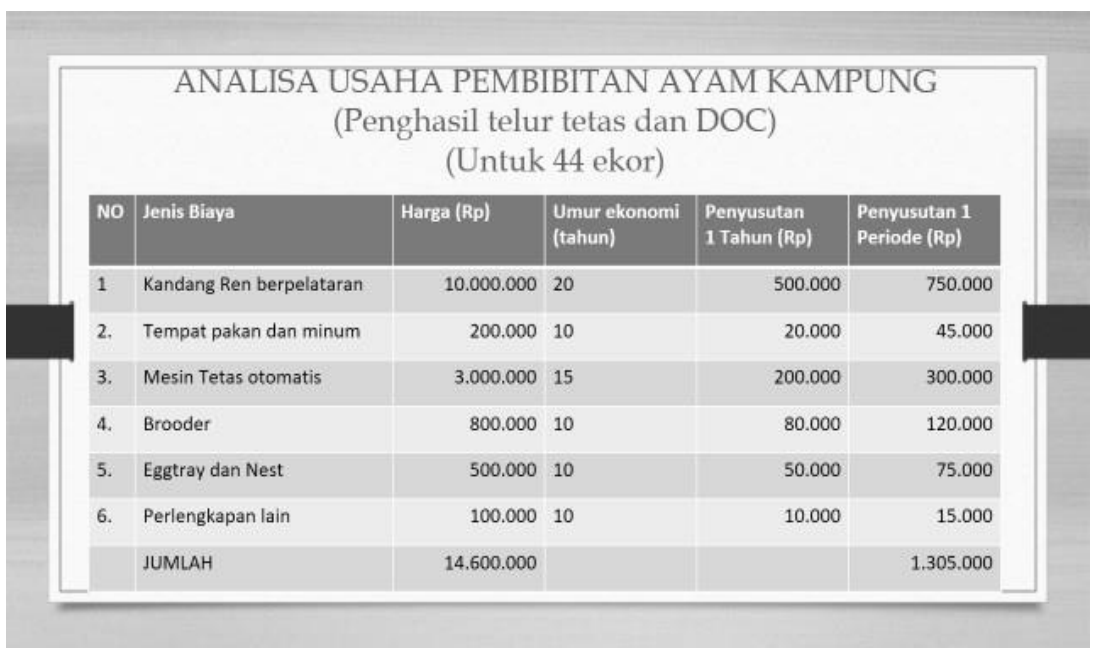

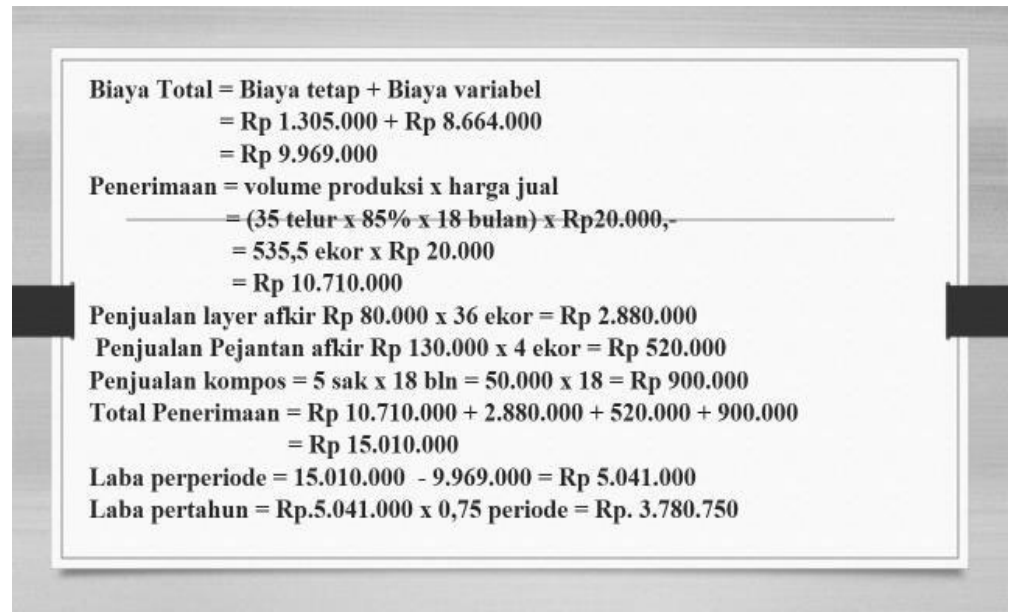


Jurnal SEMAR Vol. 7 No. 2, 2018 hal. $23-31$

ISSN: 2302-3937 | Copyright (C LPPM Universitas Sebelas Maret

Homepage: https://jurnal.uns.ac.id/jurnal-semar
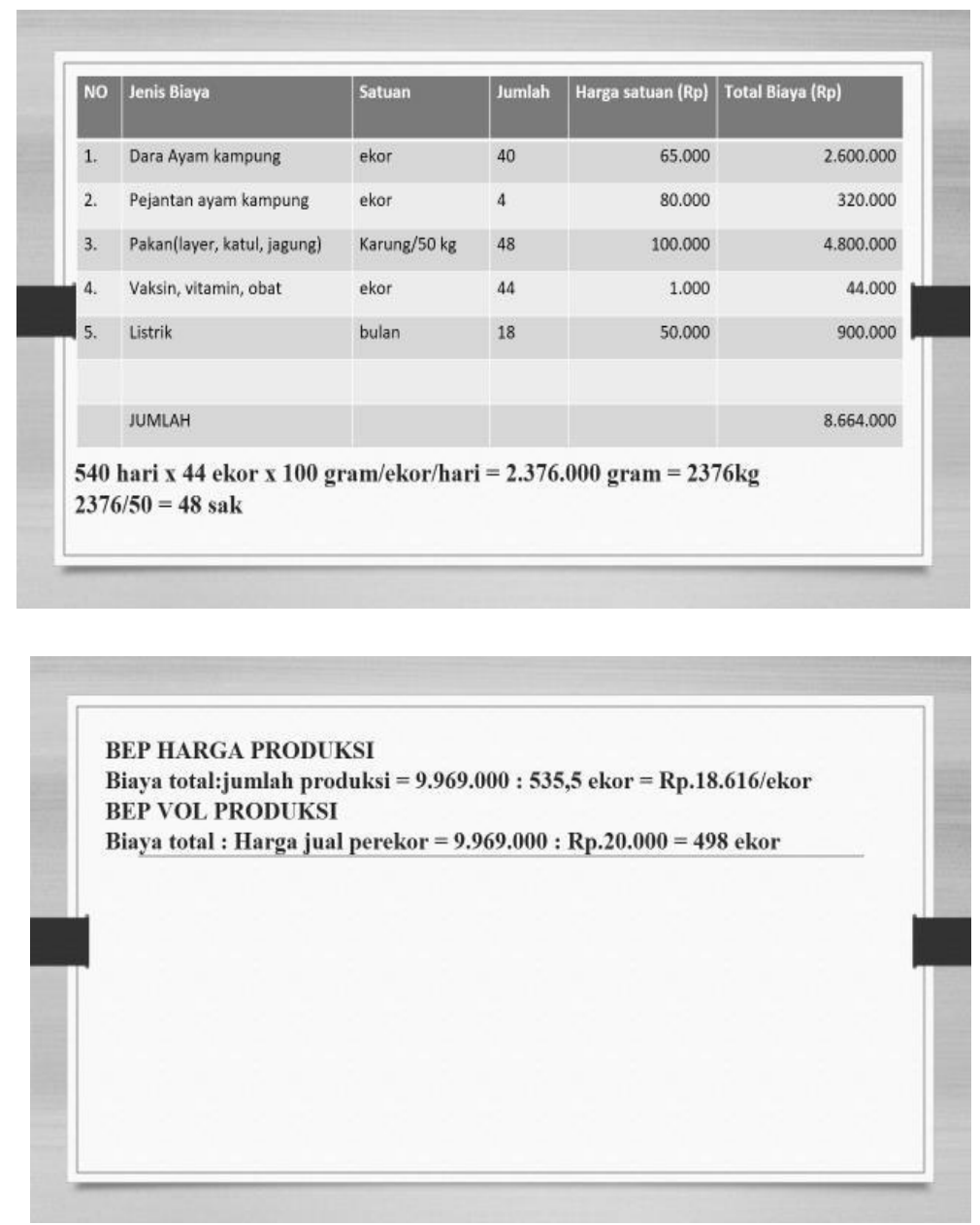

Gambar 9. Analisis usaha ayam kampung selama satu tahun

\section{RENCANA TAHAPAN BERIKUTNYA}

Rencana berikutnya adalah melanjutkan Breeding ayam kampung dan melanjutkan produksi telur serta DOC.

\section{DAMPAK PENGABDIAN}

Setelah mendapatkan pelatihan dan penyuluhan tentang beternak ayam kampung, mitra terutama ustad ustadah mengalami peningkatan dan tambahan ketrampilan, pengetahuan, selain keuntungan dari penjualan telur dan ayam kampung. Bahkan kedua mitra ingin membesarkan usahanya dengan menambah mesin tetas dan luasan kandang, sehingga usaha beternak ayam kampung ini menjadi berkelanjutan. Tidak hanya dampak pada ustad ustadah saja akan tetapi tetangga dekat juga mengcopy cara pemeliharaan ayam kampung yang benar sebagai ide untuk usaha sampingan dirumah, sehingga dampak pengabdian begitu luas dan sangat bermanfaat. 
Jurnal SEMAR Vol. 7 No. 2, 2018 hal. 23 - 31

ISSN: 2302-3937 | Copyright (C LPPM Universitas Sebelas Maret

Homepage: https://jurnal.uns.ac.id/jurnal-semar

\section{KESIMPULAN}

1. Kemampuan dan ketrampilan ustad ustadah TPA Al-Ardhi dan Nurul Jadid meningkat dan diharapkan mandiri secara ekonomis. Introduksi dan pemanfaatan kandang dan peralatan berjalan dengan sangat baik. Kandang dan bibit ayam kampung di regenerasikan dengan baik.

2. Breeding yang berkelanjutan, kemampuan dalam pembukuan dan pemasaran produk juga meningkat. Pembukuan keuangan secara sederhana telah dibuat oleh kedua mitra TPA.

\section{UCAPAN TERIMA KASIH}

Dengan telah selesainya kegiatan pengabdian dan penyusunan laporan ini, terimakasih yang tidak terhingga kami sampaikan kepada pihak-pihak yang telah memberi kesempatan untuk melakukan kegiatan dan memberi bantuan baik berupa dana, ijin dan partisipasi :

1. DIKTI

2. Lembaga Penelitian dan pengabdian Pada Masyarakat (LPPM) UNS

3. TPA Al-Ardhi dan Nurul Jadid Kabupaten Sragen.

\section{DAFTAR PUSTAKA}

Kementerian Kesehatan RI, 2010. Telur Sumber Makanan Bergizi. Jakarta.

Juliansyah. 2016. Langsung Untung Beternak Ayam Kampung. Media Pressindo. Yogyakarta.

Sartika, Tike. 2016. Panen Ayam Kampung 70 Hari. Penebar Swadaya. Jakarta. 